\title{
Treatment of MAS and HLH
}

\author{
Alexandre Belot ${ }^{1,2}$ \\ From 21st European Pediatric Rheumatology (PReS) Congress \\ Belgrade, Serbia. 17-21 September 2014
}

Macrophage activation syndrome (MAS) is a lifethreatening complication of inflammatory disease, occurring secondary to a complex interplay of genetic factors, drugs, infectious agents and immunological anomalies. Early identification and aggressive treatment are mandatory to prevent fatal evolution.

Precipitating factors should be looked for and eventually removed such as infections (leishmania, EBV, Parvo $B 19 . .$.$) or drug exposure. Epstein Barr Virus (EBV) is a$ major cause of MAS and anti-EBV therapies can be helpful to control MAS.

First line therapies usually include high-dose steroids associated to cyclosporine. In the context of primary hemophagocytic lymphohistiocytosis (HLH), bone marrow transplantation is the only treatment able to cure the disease. In inflammatory disease with secondary $\mathrm{HLH}$, a few case reports indicate an efficacy of anti-cytokine treatment (anti-IL1, anti-IL6, anti-TNF $\alpha$ ). However, a role of these cytokines in MAS development remains unproven. To investigate whether the IL-1 pathway might contribute to MAS, we compared IL-1RA-/- to wild type mice after stimulation with CpG, a TLR9 activator. TLR9-induced MAS was similar in the two groups, suggesting that IL-1 excess is not a major inducer of MAS. More interestingly, recent data implicate IFN $\gamma$ as a crucial factor in MAS onset. Thus, the inhibition of secreted IFN $\gamma$ might represent an interesting therapeutic avenue worthy of further investigation.

\section{Disclosure of interest}

None declared.

Authors' details

${ }^{1}$ Pediatric Nephrology, Rheumatology and Dermatology, Hopital Femme Mère Enfant, Hospices Civils de Lyon, France. ${ }^{2}$ U1111, INSERM, Lyon, France.

Published: 17 September 2014

${ }^{1}$ Pediatric Nephrology, Rheumatology and Dermatology, Hopital Femme Mère Enfant, Hospices Civils de Lyon, France

Full list of author information is available at the end of the article
doi:10.1186/1546-0096-12-S1-18

Cite this article as: Belot: Treatment of MAS and HLH. Pediatric

Rheumatology 2014 12(Suppl 1):18.
Submit your next manuscript to BioMed Central and take full advantage of:

- Convenient online submission

- Thorough peer review

- No space constraints or color figure charges

- Immediate publication on acceptance

- Inclusion in PubMed, CAS, Scopus and Google Scholar

- Research which is freely available for redistribution
C Biomed Central
C Biomed Central

(c) 2014 Belot; licensee BioMed Central Ltd. This is an Open Access article distributed under the terms of the Creative Commons Attribution License (http://creativecommons.org/licenses/by/4.0), which permits unrestricted use, distribution, and reproduction in any medium, provided the original work is properly cited. The Creative Commons Public Domain Dedication waiver (http://creativecommons.org/publicdomain/zero/1.0/) applies to the data made available in this article, unless otherwise stated. 